\title{
Infrared thermography analysis with a low-cost camera in plaster sculptures of museum collections
}

\author{
Rui Bordalo, Salomé Carvalho, José Guilherme Abreu, Eduarda Vieira
}

\begin{abstract}
Infrared thermography (IRT) is a non-destructive and non-invasive technique that provides the possibility to investigate the surface of sculptures for the detection of subsurface features and anomalies such as delamination, layer structure, fillings, and defects. IRT has been widely used in buildings and large structures, as well as in works of art such as bronze sculptures and paintings. This article describes the application of active infrared thermography, using a portable low-cost IRT camera, in the examination of plaster sculptures, a material where it has not yet been applied to. In particular, it was used in two plaster sculptures by 19th-century Portuguese artist Soares dos Reis, within a wider project (GEO-SR) aimed at the study of his work. The results indicate that thermography is a suitable technique with a great potential to detect alterations under the surface of plaster, revealing a new look into its manufacturing and conservation.
\end{abstract}

Keywords: IRT, sculpture, plaster collections, GEO-SR project, sustainability

\section{Análisis de termografía infrarroja con cámara de bajo coste en esculturas de yeso en colecciones de museos}

Resumen: La termografía infrarroja (IRT) es una técnica no destructiva y no invasiva que ofrece la posibilidad de estudiar la superficie de las esculturas para la detección de características y anomalías como delaminación, estructura de las capas, rellenos y defectos. La IRT se ha utilizado ampliamente en edificios y grandes estructuras, así como en obras de arte como esculturas de bronce y pinturas. En este artículo se describe la aplicación de la termografía infrarroja activa, utilizando una cámara portátil de bajo coste, en el examen de esculturas de yeso, un material al que todavía no se había aplicado hasta ahora. En particular, se utilizó en dos esculturas de yeso del artista portugués del siglo XIX Soares dos Reis, dentro de un amplio proyecto dedicado al estudio de su obra (GEO-SR). Los resultados indican que es una técnica adecuada con un gran potencial para detectar alteraciones bajo la superficie, permitiendo una nueva mirada a su construcción y conservación.

Palabras clave: IRT, escultura, colecciones de yeso, proyecto GEO-SR, sostenibilidad

\section{Análise termográfica por infravermelhos com câmara de baixo custo em esculturas de gesso em colecções museológicas}

Resumo: A termografia por infravermelhos (infrared thermography - IRT) é uma técnica não destrutiva e não invasiva que oferece a possibilidade de estudar a superfície das esculturas para a detecção de características e anomalias, tais como delaminação, estratigrafia, preenchimentos e defeitos. O IRT tem sido amplamente utilizado em edifícios e grandes estruturas, assim como em obras de arte como esculturas e pinturas em bronze. Este artigo descreve a aplicação de termografia infravermelha activa, utilizando uma câmara manual de baixo custo, no exame de esculturas de gesso, um material ao qual ainda não tinha sido aplicado. Em particular, foi utilizado em duas esculturas em gesso de finais do século XIX, da autoria do escultor português António Soares dos Reis, como parte de um extenso projecto dedicado ao estudo da sua obra (GEO-SR). Os resultados indicam que é uma técnica com um grande potencial para detectar alterações debaixo da superfície, permitindo um novo olhar sobre a sua construção e conservação.

Palavras-chave: IRT, escultura, colecções de gesso, projecto GEO-SR, sustentabilidade 


\section{Introduction}

The correct assessment of the preservation condition of an artefact, a monument or work of art is among the many objectives of heritage conservation when a simple visual observation is not sufficient. This paper aims to assess the suitability of using infrared thermography (IRT) for the examination of plaster sculptures as a support for the study of its conservation and construction technique. This technique is especially useful to detect subsurface features that are often undetected by other non-destructive techniques (NDT) such as X-radiography or infrared reflectography. Also, it does not present any potential interference or adverse effects with other analyses such as, for example, thermoluminescence dating, nor presents any safety issues, being possible to use it quite easily at a conservation workshop.

This paper's goal meets the rising awareness in Conservation on environmental and economical sustainability. At the present moment Conservation as a science walks towards sustainability in all its meanings. Both the IIC and ICOM-CC agreed, at their Hong Kong and Melbourne conferences (both in September 2014), a declaration on sustainability: regarding museums and other similar institutions, they are expected to "[...] seek to reduce their carbon footprint and environmental impact to mitigate climate change, by reducing their energy use and examining alternative renewable energy sources" (ICOM-CC 2014). This relates directly to simpler management strategies that include preventive conservation and risk assessment strategies such as the one applied in this study. GEO-SR project ${ }^{[1]}$ also aims to apply and systematize the use of preexisting technology in a less complex way, using portable, lowcost, low energetic consuming equipment in a museum environment.

\section{Thermographic analysis}

IRT visualises the temperature of objects and its distribution, allowing thus the identification of subsurface defects and features in materials (Maldague 1993). This technique is based on the propagation of heat through the material surface. Typically, thermography uses medium wavelength (3-5 $\mu \mathrm{m})$ or long wavelength $(8-14 \mu \mathrm{m})$ to measure the diffusion of heat through a material, as opposed to near infrared (1-3 $\mu \mathrm{m})$ which is used in infrared reflectography. IRT techniques fall under two types, passive and active. Passive IRT is used with objects or materials that are naturally at different temperature than the surrounding environment and is often used in industrial control, forest fire watching, medical examination, and study of buildings and historic structures. In this approach, since no external thermal stimulation is applied, the temperature distribution at the surface and the subsurface structures is not related, providing mostly qualitative information. Active IRT requires an external artificial heat source, such as flash lamps, lasers or others, to increase the temperature of the object above its regular temperature, after which the thermal response of the object as it returns to its previous thermal equilibrium is measured with an infrared camera. Because the thermal diffusion is different in the presence of defects, since they retard or accelerate the heat flow, these appear as areas of different temperatures than the rest of the surface. This method allows for both quantitative and qualitative information. The properties of each type of external heat source, namely different heating dependencies, affect differently how the object in analysis reacts to them which is the base for different IRT methods such as lock-in IRT (periodic heating), flash IRT (flash lamps), and step IRT (step heating and cooling).

The use of thermography in heritage and conservation related research dates from at least some decades (Miller 1977; Accardo et al. 1983; Kulicki 1991), and since it has increasingly been used to study historic buildings and structures (Grinzato et al. 1998; Moropoulou et al. 2000; Grinzato et al. 2002 a; Avdelidis et al. 2004 a; Cabrelles et al. 2009; Avdelidis 2018), as well as different types of cultural heritage objects such as marble (Avdelidis et al. 2004 b; Avdelidis, Moropoulou, 2004), bronzes (Mercuri et al. 2011; Orazi et al. 2011; Orazi et al. 2016; Mercuri et al. 2017), frescoes (Grinzato et al. 1994; Grinzato et al. 2002 b; Candoré et al. 2008; Bendada et al. 2010; Bartz et al. 2012), paintings (Miller 1977; Candoré et al. 2008; Blessley et al. 2010; Gavrilov et al. 2013; Gavrilov et al. 2014), sculpture (Fontana et al. 2004; Orazi 2011; Han 2014; Di Tuccio et al 2015), ceramics and terracotta (Mercuri et al. 2011), and books (Mercuri et al. 2011; Mercuri et al. 2017). Concerning IRT applied to plaster as material, most publications focused on wall paintings and frescoes, and not sculpture. Unfortunately, the authors were not able to locate any publication that used IRT to plaster sculptures.

\section{Plaster Sculptures}

This article deals with the study of plaster sculptures by Portuguese artist António Soares dos Reis (1847-1889) that belongs to the Soares dos Reis National Museum (Porto, Portugal). The museum holds a large collection of plaster, bronze, and marble sculptures by this artist, one of the finest Portuguese sculptors. Plaster is a fascinating material and it has been used since Antiquity for its low cost, quick hardening, and the potential to replicate works of art and other sort of objects. Plaster copies of GrecoRoman sculptures were very common in the $19^{\text {th }}$-century as they were used for education and training purposes in schools and art academies. However, plaster sculptures were also an integrant part of the sculptural process, sometimes as studies or as an end-result per se, although more often than not they were intended as a model for bronze sculptures. Nonetheless plaster's fragility as a material, the flexibility in its use allowed it to become part of centrepieces in newly founded museums, in Europe and the USA (Fitzpatrick Nichols 2006). 
The study of $19^{\text {th }}$ century sculptural techniques in Portugal, namely of plaster casts, is still mostly undone. This subject is being addressed from a holistic point of view though a research project dedicated to the study of the work of Soares dos Reis, in which this study is included. In particular, this article focuses on the application of active IRT applied to two $19^{\text {th }}$-century plaster sculptures in order to evaluate the application of infrared thermography to plaster casts and the feasibility of using a low-cost thermal camera for this purpose. Even though the results obtained are mostly of a qualitative nature, its usefulness lies in obtaining a visualisation of repairs or fillings that cannot be seen at naked eye or with other readily available and easy to use techniques.

In order to achieve this, two sculptures were selected from among the large museum collection [Figures 1-2]. Both sculptures are made of gypsum and present remains of a paint layer or patina already discoloured or missing in some parts. The first, "Head of a Black Man" from 1873 (83 Esc

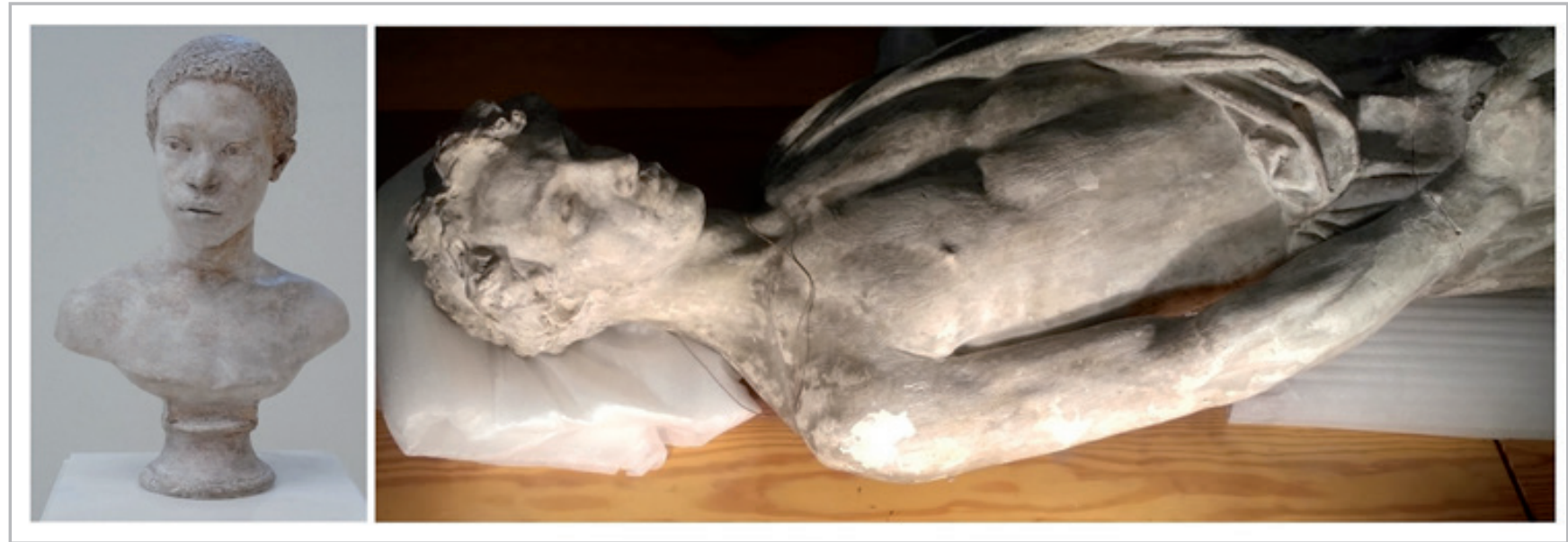

Figure 1.- Selected sculptures for the study, left: "Head of a Black Man" from 1873 (83 Esc MNSR); right: "The Work" from 1876 (87 Esc MNSR), both from the National Museum Soares dos Reis (Porto, Portugal).

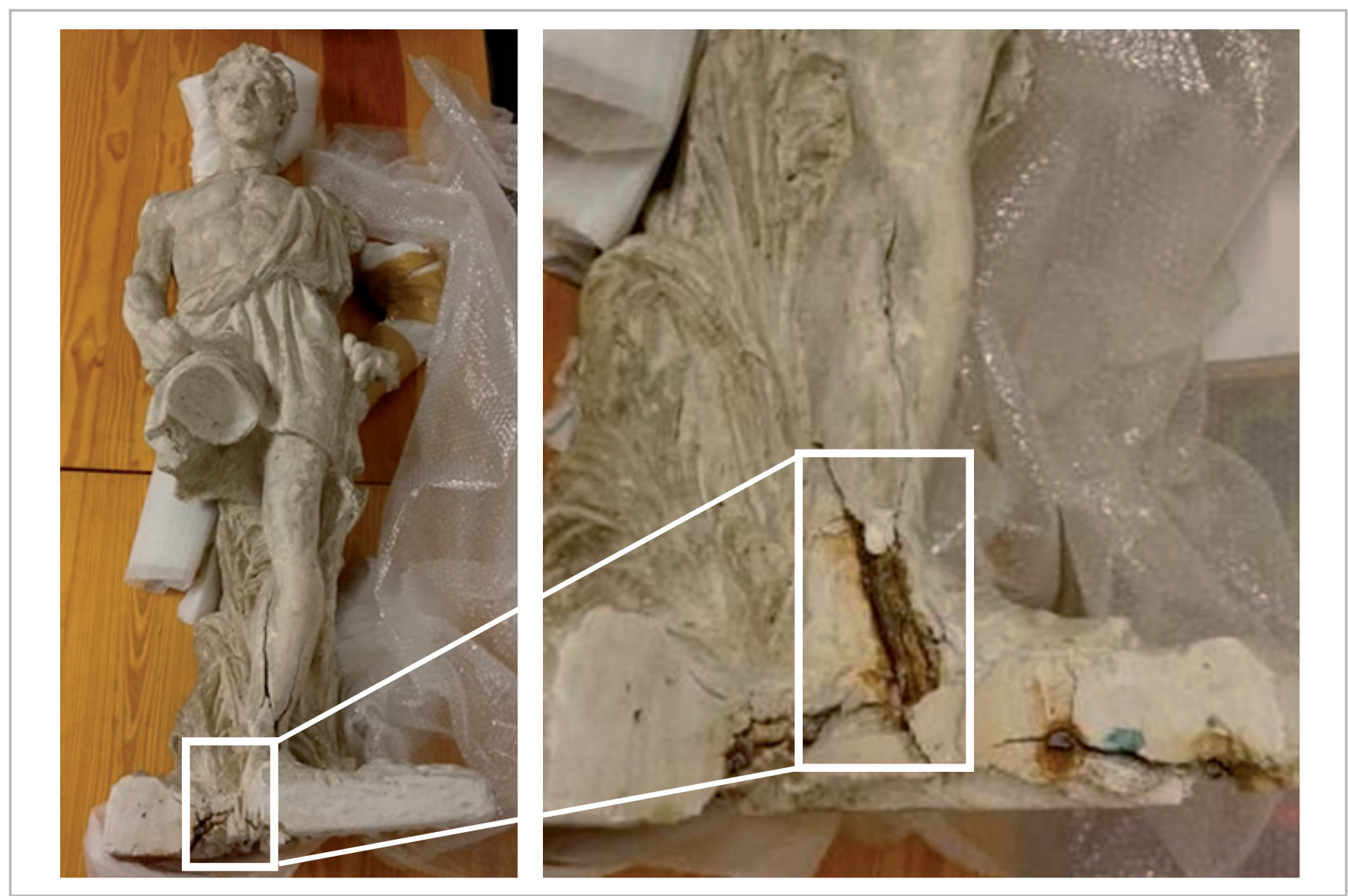

Figure 2.- General view (left) of "The Work" from 1876 (87 Esc MNSR) and detail of its current condition (right), with a highlight of the iron core and the stress cracks it induced on the plaster. 
MNSR), is placed in the permanent exhibition circuit and presents no visible detachments, cracks, or other surface alteration. The second plaster sculpture is "The Work" from 1876 (87 Esc MNSR), an allegory representing a naked masculine Figure, located at the museum storage facilities since it is badly damaged, lacking part of its base, partly due to internal stresses caused by the oxidation of the sculpture's inner iron skeleton, as well presenting several cracks in the arms and hands and a detached column. The story of the damage at the base, the most severe of all, is unknown but it may have been done after the execution of its bronze version in 1959.

Most plaster sculptures, depending of their shape, volume and weight, do require some form of internal reinforcement, being as vegetal fibres within the core of plaster, or an internal metallic structure or skeleton, being common in the $19^{\text {th }}$-century the use of iron cores. However, in time, the oxidation and consequent volumetric expansion of the metal core is known to create tensions and cracks, such as in the case of "The Work". Environmental conditions at the museum are naturally controlled in order to minimise stresses to the artworks. No analyses have ever been made to these sculptures and the assessment of their conservation condition beyond any visual observation was important to be made at the present moment. Analyses to the plaster and paint layers are underway and after the conclusion of the GEO-SR project, this data will be used for the conservation and restoration intervention that is planned.

\section{Methodology}

As previously mentioned, since the sculptures are in museum environment aimed at keeping the artefacts under stable thermal and environmental conditions, an active approach was necessary to induce temperature differences of at least some few degrees. Given that both sculptures are made of gypsum and are covered with a paint layer and/or patina, it was not expected to find different thermophysical properties, such as the conductivity, at the surface except perhaps in lacunae areas of material or patina. As such, there was no immediate concerns regarding small temperature increases that could endanger the sculptures.

The two sculptures were selected due to their contrasting conservation state and heated with two 150W halogen lamps placed at approximately $45^{\circ}$ to the object and at close proximity $(\sim 50 \mathrm{~cm})$. The sculptures were heated in intervals of 10 seconds, 30 seconds, 60 seconds, 2 minutes, 5 minutes, and 10 minutes after which the lamps were disconnected and thermograms taken at intervals of 15 seconds in order to observe changes at the surface. No overheating of any part of the sculptures was detected.

Thermal imaging was performed with a low-cost handheld infrared camera model EC060V (TROTEC, Germany).
The camera is equipped with a microbolometer UFPA detector with a spectral range of 8-14 $\mu \mathrm{m}$ and a resolution of $160 \times 120$ pixels. The temperature range is from $-20^{\circ} \mathrm{C}$ to $+250^{\circ} \mathrm{C}$ with an accuracy of $\pm 2{ }^{\circ} \mathrm{C}, \pm 2 \%$ of the measured value. The camera operates only with manual focus. The material's emissivity was considered as being 0.86 . Also, environmental conditions were taken in account and introduced into the camera internal software ("Head of a Black Man": 22 C, 61\% RH; "The Work": 19.4 C, 78\% RH). The images were processed in IC-Report v.2.6.0 software, allowing to import the native SAT file and export them into JPG or BMP file formats.

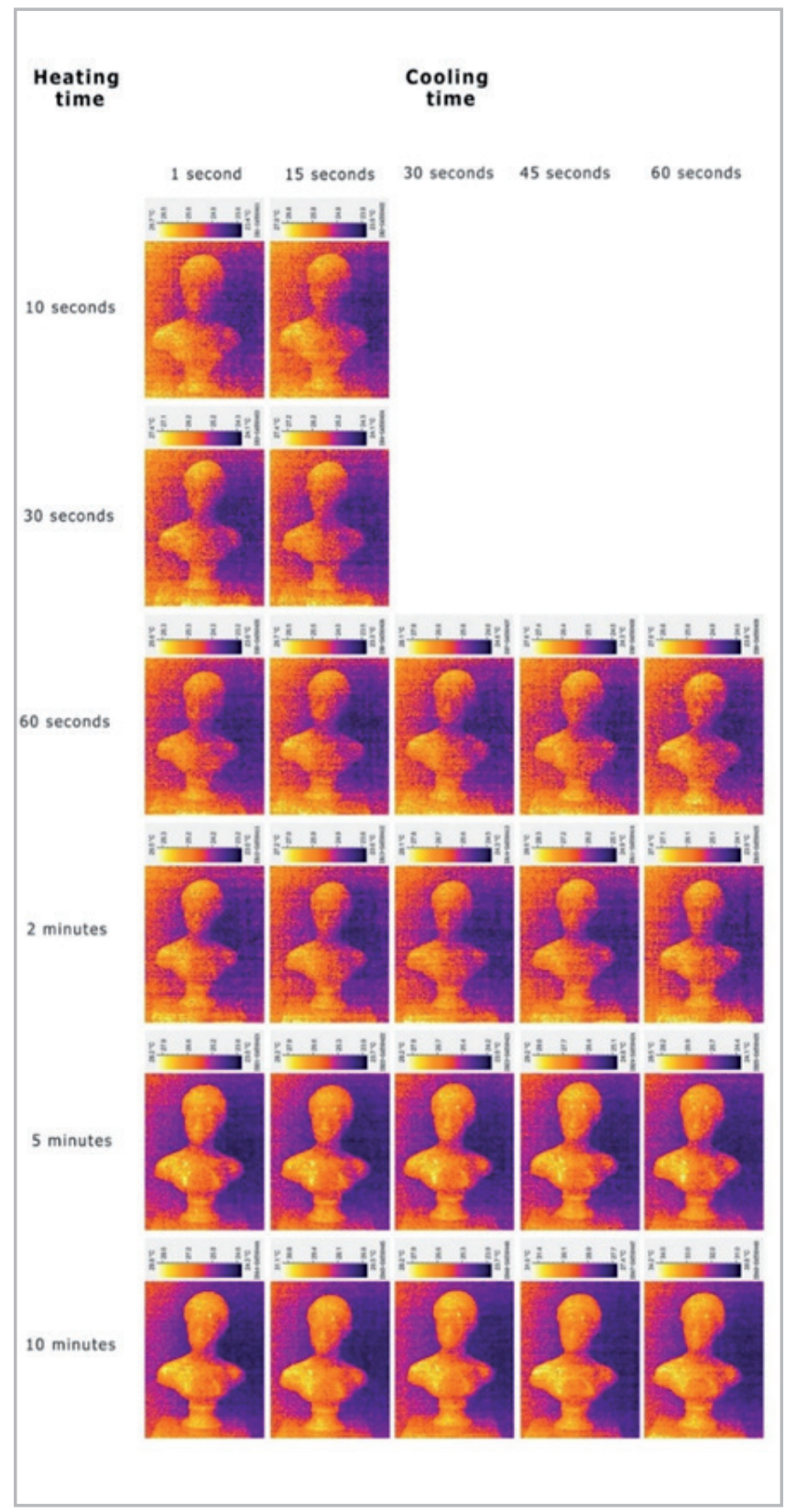

Figure 3.- Thermograms of the sculpture "Head of a Black Man" (1873) showing the thermal response of the sculpture as it cools down, irradiating excess thermal energy, after being heated with an external heat source for several periods of time. It can be noticed some subsurface alterations in the periods of more intense irradiation. 


\section{Results and Discussion}

The thermographic results obtained in the plaster sculptures are reported in this work. Since no literature was found on the application of active IRT on plaster sculptures, it was decided to take a step by step approach. Thus, it was irradiated at periodic intervals and then photographed, also at periodic intervals, while it returned to its thermal equilibrium as shown in Figure 3.

\section{- Head of a Black Man (1873)}

As demonstrated in Figure 3, the bust of "Head of a Black Man" (1873) was irradiated for several periods of times but only started revealing some subsurface features after being irradiated for at least 5 minutes. As it can be also seen in the same Figure, there is no relevant differences observed during the cooling time of the sculpture. Once these subsurface features were detected, a closer look was given to these, only limited to the camera resolution and manual focus.

Figure 3 shows a comparative analysis of the sculpture. In the thermograms of the bust, and especially of the detail of the face, at least two larger areas and some few smaller ones can be observed at a lighter colour, indicating a higher temperature. These areas indicate the presence of a material with slightly different thermophysical properties than the material that surrounds it. In this case, it is shown at a different colour because it has a lower heat diffusion, helping to retain the heat for a longer period. These are most likely fillings or corrections that the artist needed to perform. As it can be seen in Figure 4, the areas of these variations are not observed at naked eye. Figure 5 shows the same areas as Figure 4 but seen from profile, showing much better their

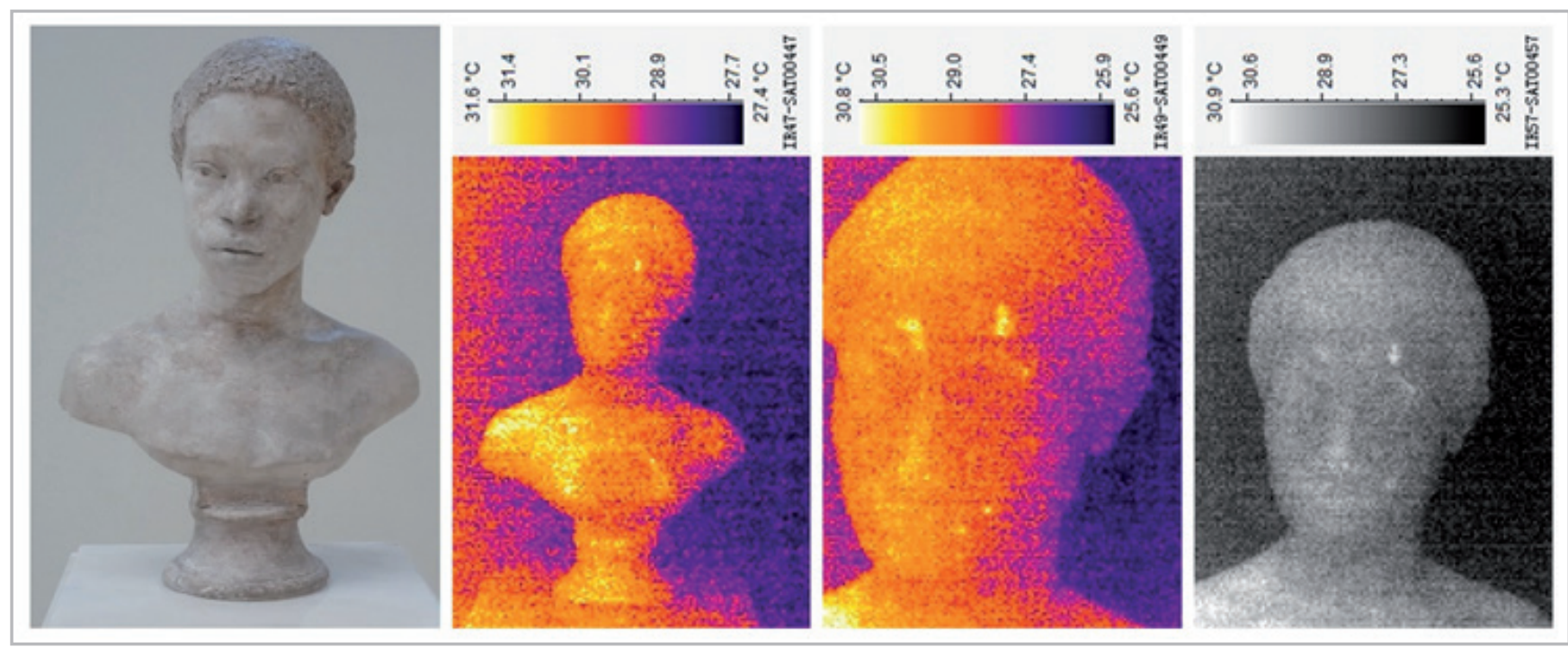

Figure 4.- Front view of "Head of a Black Man" (1873) and respective thermograms with an irradiation time of 10 minutes. On the right, two thermograms, with colour and B/W filters, show in detail the front view of some few subsurface alterations, namely two larger ones in the eyebrow and temple. Using both filters, some areas gain some visibility.

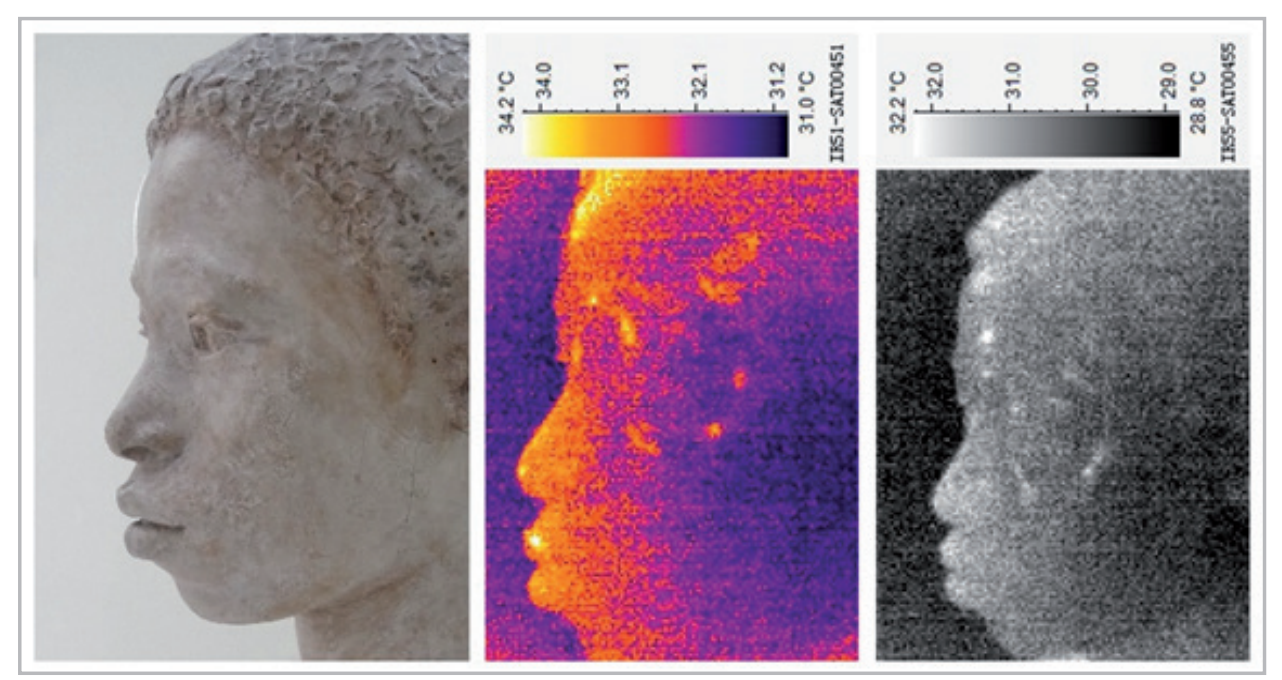

Figure 5.- Detail of a close-up of the face of "Head of a Black Man" (1873) and thermograms of the same area, in colour and B/W, after an irradiation time of 10 minutes. It is possible to observe several subsurface alterations in the area around the left eye, temple, and the cheek's upper side which are not visible at naked eye. 


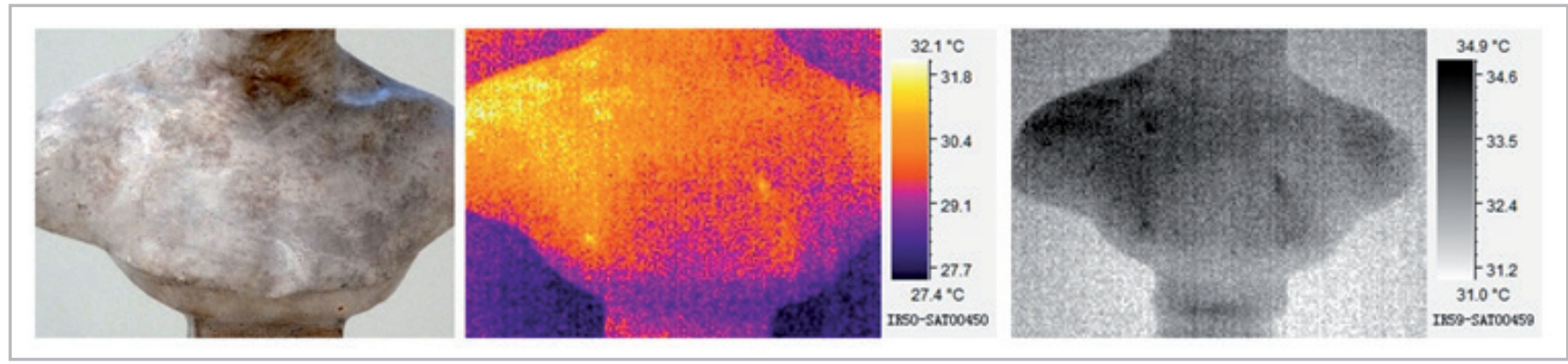

Figure 6.- Detail of the chest of "Head of a Black Man" (1873) and thermograms of the same area, in colour and B/W, after an irradiation time of 10 minutes. It is possible to observe three main subsurface alterations at a higher temperature than the material surrounding them.

distribution over the cheek. Once again, apparently these alterations are not seen at naked eye although they can be disguised by the patina. It should be noted that, as observed in Figure 4, the bust presents a vertical microcrack between the jaw and the ear which is not observed in any thermogram at any time. Figure 6 shows a detail of the chest where three large points of lower heat diffusion can also be seen. The lower heat diffusion of the material shows that is a material slightly different from the original, most likely a gypsum made at a later stage after the drying up of the sculpture with a variation of its composition or mineral concentration.

\section{-The Work (1876)}

This is a full body sculpture of almost natural size that is in the museum storage facilities and it kept horizontally which prevented a uniform heat distribution of the entire sculpture.
Thus, the heating was performed with three lamps across the right side of the sculpture and thermograms were collected on that side only. With similar results than the previous bust [Figure 2], thermograms of the analysis performed to the base of the sculpture, where the inner metal skeleton is visible, did not show any relevant information up to 5 minutes [Figure $6 \mathrm{~B}$ ] and at 10 minutes [Figure $6 \mathrm{C}$ ] revealed to be quite homogeneous. As expected, the metal, as the most conductive material, did absorb the most thermal energy. This analysis can provide further information on the diffusion of metal oxides throughout the plaster, which can be useful to further conservation interventions.

On the upper side of the sculpture, analysis to the head did not reveal any relevant information, being the surface quite homogeneous. However, the arm [Figure 7] did reveal some subsurface features, located in the shoulder and elbow, similar to those observed in the head of the previous
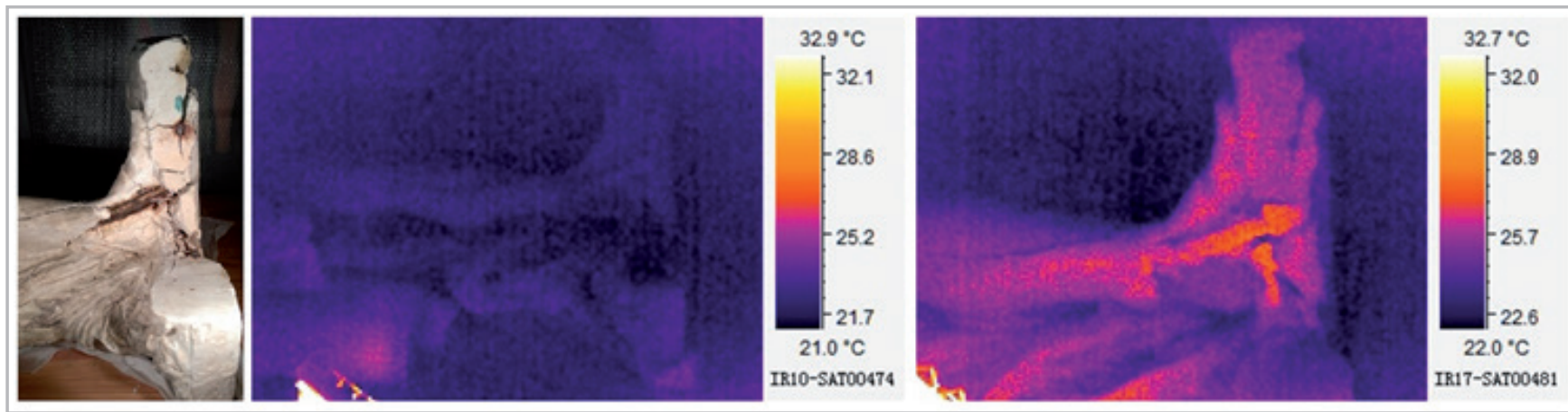

Figure 7.- Detail of the base of "The Work" (1876) and thermograms taken at 5 minutes and 10 minutes, respectively. The heating of the iron core is only visible at the higher irradiation temperature while the remaining material seems to be quite uniform.
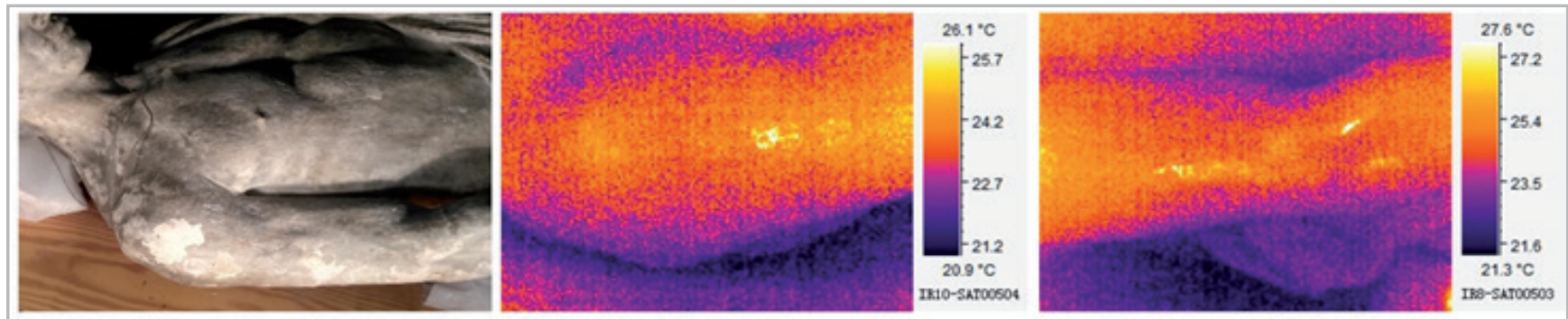

Figure 8.- Detail of the torso and right arm of "The Work" (1876) and detail thermograms of alterations located at the shoulder and elbow, both with an irradiation period of 10 minutes. Beside the subsurface features that were identified, it can also be seen that the paint layer lacunae and some damaged areas of the surface are not observable in the thermograms. 
sculpture. Once again, these are not visible at naked eye, most likely because it is covered by a paint layer. Interestingly, neither the lacunae of the paint layer nor fissures located all around the sculpture, such as in the wrist, are not visible in the thermograms.

\section{Conclusions}

The present paper reports the results of active IRT analysis applied to the study of plaster sculptures. It is shown that active IRT was able to identify subsurface features that other NDT techniques usually are not able to recognise. The analysis of two plaster sculptures from the National Museum Soares dos Reis was able to locate features likely associated with repairs by the artist, confirming the viability of using active IRT for the identification of subsurface features in plaster sculptures but not other anomalies such as lacunae of the paint layer or fissures or volumetric lacunae. Further work should be made in order to optimise the thermal irradiation conditions in order to highlight or to enhance other subsurface features not yet detected. IRT was found to be a simple, fast, and reliable technique to be used in a museum setting. Furthermore, the low-cost camera may present some disadvantages when compared with higherend cameras, such as lower resolution and sensitivity, but with a price in the order of $5 x$ to $10 x$ cheaper, its usefulness is more than compensated.

\section{Acknowledgements}

This paper is one of a series dedicated to the study of the sculptures by Soares do Reis, within the GEO-SR project - Multidisciplinary approach to alteration, alterability and conservation of Soares dos Reis geomaterial sculpture: breaking boundaries in museum paradigms and creating value in changing societies through Cultural Heritage"(funding by FEDER and FCT, reference number 031304). We also like to acknowledge the collaboration of Soares dos Reis National Museum (Directorate-General for Cultural Heritage).

\section{Notes}

[1] GEO-SR - Multidisciplinary approach to alteration, alterability and conservation of Soares dos Reis' geomaterial sculpture: breaking boundaries in Museum paradigms and creating value in changing societies through culture (CITAR, Escola das Artes, Universidade Católica Portuguesa, Porto, Portugal, in collaboration with University of Minho, University of Aveiro and Directorate-General for Cultural Heritage/National Museum of Soares dos Reis, Porto, Portugal.

\section{References}

ACCARDO, G.; BOTTONI, M.; FABRETTI, G.; SANTIN, V. (1983). “Esame delle disomogeneita strutturali in manufatti mettalici mediante termografía". in Proceedings of the Conferenza internazionale su le prove non-distruttive nella conservazione delle opere d'arte, 1.1-1.15.

AMBROSINI, D.; DAFFARA, C.; DI BIASE, R.; PAOLETTI, D.; PEZZATI, L., BELLUCCI, R.; BETTINI, F. (2010). "Integrated reflectography and thermography for wooden paintings diagnostics". Journal of Cultural Heritage, 11: 196-204. https://doi.org/10.1016/j. culher.2009.05.001

AVDELIDIS, N.P.; MOROPOULOU, A.; DELEGOU, E.T. (2004 a). "A thermographic study for the assessment of historic structures", in Proceedings of the 2004 International Conference on Quantitative InfraRed Thermography. QIRT Council. https://doi.org/10.21611/ girt.2004.054

AVDELIDIS, N.P.; DELEGOU, E.T.; ALMOND, D.P.; MOROPOULOU, A. (2004 b). "Surface roughness evaluation of marble by 3D laser profilometry and pulsed thermography". NDT \& E International, 37: 571-575. https://doi.org/10.1016/j.ndteint.2004.03.002

AVDELIDIS, N.P.; MOROPOULOU, A. (2004). "Applications of infrared thermography for the investigation of historic structures". Journal of Cultural Heritage, 5: 119-127. https://doi.org/10.1016/j. culher.2003.07.002

AVDELIDIS, N.P. (2018). "IR Thermography as a Non-destructive Tool for Materials Characterisation and Structural Assessment of Buildings and Historic Structures", in 10th International Symposium on the Conservation of Monuments in the Mediterranean Basin, Koui, M., Zezza, F., and Kouis, D. (Eds.). Cham: Springer, 71-78.

BARTZ, W.; ROGÓŻ, J.; ROGAL, R.; CUPA, A.; SZROEDER, P. (2012). "Characterization of historical lime plasters by combined nondestructive and destructive tests: The case of the sgraffito in Bożnów (SW Poland)". Construction and Building Materials, 30: 439446. https://doi.org/10.1016/j.conbuildmat.2011.12.045

BENDADA, A.; SFARRA, S.; AMBROSINI, D.; PAOLETTI, D.; IBARRACASTANEDO, C.; MALDAGUE, X. (2010). "Active thermography data processing for the NDT\&E of frescoes", in Proceedings of the 2010 International Conference on Quantitative InfraRed Thermography. QIRT Council. https://doi.org/10.21611/qirt.2010.015

BLESSLEY, K.; YOUNG, C.; NUNN, J.; CODDINGTON, J.; SHEPARD, S. (2010). "The Feasibility of Flash Thermography for the Examination and Conservation of Works of Art". Studies in Conservation, 55: 107120. https://doi.org/10.1179/sic.2010.55.2.107

CABRELLES, M.; GALCERÁ, S.; NAVARRO, S.; LERMA, J.L.; AKASHEH, T.; HADDAD, N. (2009). "Integration of 3D laser scanning, photogrammetry and thermography to record architectural monuments", in Proceedings of the 22nd International CIPA Symposium, Kyoto, 6.

CANDORÉ, J.C.; BODNAR, J.L.; DETALLE, V.; REMY, B.; GROSSEL, P. (2008). "Approach of the measurement of thermal diffusivity of mural paintings by front face photothermal radiometry". Journal of Physics Conference Series, 214(1): 012094. https://doi. org/10.1088/1742-6596/214/1/012094 
ICOM-CC (2014). Declaration on Environmental Guidelines - ICOMCC and IIC. http://www.icom-cc.org/332/-icom-cc-documents/ declaration-on-environmental-guidelines/ [accessed 20/9/2019].

DI TUCCIO, M.C.; LUDWIG, N.; GARGANO, M.; BERNARDI, A. (2015). "Thermographic inspection of cracks in the mixed materials statue: Ratto delle Sabine". Heritage Science, 3: 10. https://doi.org/10.1186/ s40494-015-0041-6

FITZPATRICK NICHOLS, M. (2006). “Plaster cast sculpture: A history of touch". Archaeological Review from Cambridge, 21.2: 114-130.

FONTANA, R.; GAMBINO, M.C.; GRECO, M.; LUDWIG, N.; MARRAS, L.; MATERAZZI, M.; PAMPALONI, E.; PELAGOTTI, A.; PEZZATI, L. (2004). "Thermographic Analysis", in Exploring David: Diagnostic Tests and State of Conservation, Bracci, S., Falletti, F., Matteini, M., Scoplgno, R. (Eds.), Florence, 148-149.

GAVRILOV, D.; MAEVA, E.; GRUBE, O.; VODYANOY, I.; MAEV, R. (2013). "Experimental Comparative Study of the Applicability of Infrared Techniques for Non-destructive Evaluation of Paintings". Journal of the American Institute for Conservation, 52: 48-60. https://doi.org/1 $0.1179 / 0197136012 Z .0000000002$

GAVRILOV, D.; MAEV, R.GR.; ALMOND, D.P. (2014). "A review of imaging methods in analysis of works of art: Thermographic imaging method in art analysis". Canadian Journal of Physics, 92: 341-364. https://doi.org/10.1139/cjp-2013-0128

GRINZATO, E.; BISON, P.; MARINETTI, S.; VAVILOV, V. (1994). "Nondestructive evaluation of delaminations in fresco plaster using transient infrared thermography". Research in Nondestructive Evaluation, 5(4): 257-274.

GRINZATO, E.; VAVILOV, V.; KAUPPINEN, T. (1998). "Quantitative infrared thermography in buildings". Energy and Buildings, 29: 1-9. https://doi.org/10.1016/S0378-7788(97)00039-X

GRINZATO, E., BISON, P.G., MARINETTI, S. (2002 a). "Monitoring of ancient buildings by the thermal method". Journal of Cultural Heritage, 3: 21-29. https://doi.org/10.1016/S1296-2074(02)01159$\underline{7}$

GRINZATO, E.; BRESSAN, C.; MARINETTI, S.;BISON, P.G.;BONACINA, C. (2002 b). "Monitoring of the Scrovegni Chapel by IR thermography: Giotto at infrared". Infrared Physics \& Technology, 43: 165-169. https://doi.org/10.1016/S1350-4495(02)00136-6

HAN, X. (2004). "Infrared Imaging for Detection of Defects and RealTime Monitoring of a Consolidation Treatment in Stone Sculpture", in AIP Conference Proceedings. Presented at the Quantitative Nondestructive Evaluation, Green Bay: AIP, 501-506. https://doi. org/10.1063/1.1711664

KULICKI, J. (1991). "Use of Thermography as an Investigatory Method in Conservation Research - Outline of Problems", in Science, Technology and European Cultural Heritage, Proceedings of the European Symposium, Bologna: Elsevier, 566-570. https://doi. org/10.1016/B978-0-7506-0237-2.50091-5
MALDAGUE, X.P.V. (1993). Nondestructive Evaluation of Materials by Infrared Thermography. London: Springer-Verlag.

MERCURI, F.; ORAZI, N.; PAOLONI, S.; CICERO, C.; ZAMMIT, U. (2017). "Pulsed Thermography Applied to the Study of Cultural Heritage". Applied Sciences, 7(10): 1010. https://doi.org/10.3390/app7101010

MERCURI, F.; ZAMMIT, U.; ORAZI, N.; PAOLONI, S.; MARINELLI, M.; SCUDIERI, F. (2011). "Active infrared thermography applied to the investigation of art and historic artefacts". Journal of Thermal Analysis and Calorimetry, 104: 475. https://doi.org/10.1007/s10973$\underline{011-1450-8}$

MILLER, B.F. (1977). "The Feasibility of Using Thermography to Detect Subsurface Voids in Painted Wooden Panels". Journal of the American Institute for Conservation, 16: 27-35. https://doi. org/10.2307/3179562

MOROPOULOU, A.; DELEGOU, E.T.; AVDELIDIS, N.P.; KOUI, M. (2000). "Non-destructive investigation of architectural surfaces in polluted urban atmosphere". In Proceedings NDT 2000 - the 39th Conference of the British Institute of NDT, Buxton, UK, 143-148.

ORAZI, N.; MERCURI, F.; PAOLONI, S.; ZAMMIT, U.; MARINELLI, M.; SCUDIERI, F.; MECCANICA, I.; SALERNO, C.S.; GIUFFREDI, A. (2011). "Thermographic Inspection of Historical Bronze Statues", in 10th International Conference on Non-Destructive Investigations and Microanalysis for the Diagnostics and Conservation of Cultural and Environmental Heritage. Florence, Italy, 7.

ORAZI, N.; MERCURI, F.; ZAMMIT, U.; PAOLONI, S.; MARINELLI, M.; GIUFFREDI, A.; SALERNO, C.S. (2016). "Thermographic analysis of bronze sculptures". Studies in Conservation, 61: 236-244. https:// doi.org/10.1179/2047058415Y.0000000025

POKSINSKA, M.; CUPA, A.; SOCHA-BYSTRON, S. (2008). "Thermography in the investigation of gilding on historical wall paintings", in Proceedings of the 2008 International Conference on Quantitative InfraRed Thermography, QIRT Council. https://doi. org/10.21611/qirt.2008.16 0407

\section{Author/s}

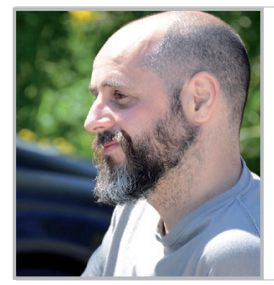

\section{Rui Bordalo}

rmbordalo@gmail.com

Universidade Católica Portuguesa, School of Arts, Research Center for the Science and Technology of the Arts, Portugal https://orcid.org/0000-0003-2852-1345

Rui Bordalo is an integrated researcher at CITAR (Research Centre in Science and Technology of the Arts) at Universidade Católica Portuguesa. He graduated in Art Conservation from the Polytechnic Institute of Tomar (2003), holds a PhD from the Courtauld Institute of Art, University of London (2011), and a postgraduation in Applied Informatics at ISCTE, Lisbon (2018). His area of research is the analytical and technical study of artist's materials and techniques, namely in paintings and sculptures, and the application of digital technologies 
to Cultural Heritage. Currently, he is developing research on a project focused on the geomaterial study and conservation of Soares dos Reis works. He has published extensively, and supervised a few master's and doctoral theses.

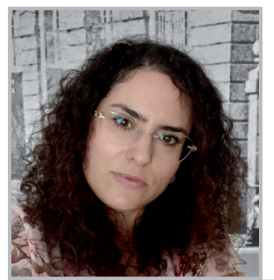

\section{Salomé Carvalho}

salomecarvalho@mnsr.dgpc.pt

Soares dos Reis National Museum

https://orcid.org/0000-0002-1669-8883

Salomé de Carvalho is conservator-restorer at Soares dos Reis National Museum (Directorate-General for Cultural Heritage DGPC - Portugal), invited lecturer and researcher at Universidade Católica Portuguesa - School of Arts / CITAR (Research Centre in Science and Technology of the Arts). She has a PhD in Conservation and Restoration (2013) and graduated in Art, Conservation and Restoration from Universidade Católica Portuguesa (2006).

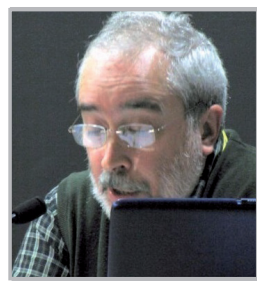

\section{José Guilherme Abreu}

jgabreu@ucp.pt

Universidade Católica Portuguesa, School of Arts, Research Center for the Science and Technology of the Arts, Portugal https://orcid.org/0000-0003-4022-7771

José Guilherme Abreu holds a PhD in Contemporary Art History (FCSH-UNL). He is invited auxiliary lecturer at the School of Arts - Universidade Católica Portuguesa, and a senior researcher at CITAR. Since 2018, he is Director of the Public Art Information, Research and Intervention Network. Since 2017, he is Secretary of Association Raymond Abellio de Recherches et Études, in Paris. He is author of several books and articles in national and international scientific journals and has supervised MA and PhD thesis. His main research domains are public art and modern and contemporary art history. In 2009, his PhD thesis attained the Ignasi de Lecea Public Art Award, by Barcelona's University Research Centre POLIS.

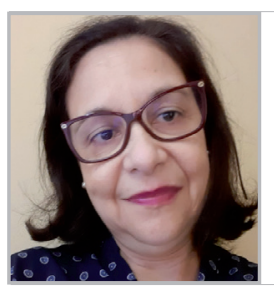

\section{Eduarda Vieira}

evieira@ucp.pt

Universidade Católica Portuguesa, School of Arts, Research Center for the Science and Technology of the Arts, Portugal http://orcid.org/0000-0002-0620-080X

Eduarda Vieira holds a PhD in Conservation and Restoration of Historic and Artistic Heritage by the Polytechnic University of Valencia (Spain), and a Master degree in Architectonic Conservation by the Évora University (Portugal). She is currently Assistant professor at the School of Arts of the Portuguese Catholic University (Conservation of Inorganic Materials), where she coordinates the $\mathrm{PhD}$ program in Conservation and Restoration of Cultural Heritage. She is the director of the Research Centre of Science and Technology of the Arts (CITAR) and editor of the Studies in Conservation and Restoration - ECREstudos de Conservação e Restauro journal. She is also a member of ICOMOS and ICOM and researcher in several projects related with Preventive Conservation and Green Conservation besides supervising several $\mathrm{PhD}$ and master thesis.
Artículo enviado el 08/01/2021 Artículo aceptado el 17/08/2021

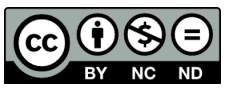

https://doi.org/10.37558/gec.v20i1.879 